\title{
PENGEMBANGAN SOAL UNTUK KEMAMPUAN PEMECAHAN MASALAH MATEMATIS SISWA KELAS XI SMA
}

\author{
Eni Ayu Setia Ningsih ${ }^{1}$, Nyayu Masyita Ariani ${ }^{2}$, Mardiah Syofiana ${ }^{3}$ \\ Universitas Muhammadiyah Bengkulu $\mathrm{u}^{1,2,3}$ \\ nyayu.masyita@gmail.com ${ }^{2}$, sofya203@gmail.com
}

\begin{abstract}
ABSTRAK
Tujuan penelitian ini untuk menghasilkan beberapa soal standar yang valid dan praktis berdasarkan kemampuan pemecahan masalah matematika siswa SMA. Penelitian ini dilakukan dengan menggunakan prosedur Tessmer yang terdiri dari tahap preliminary, self-evaluation, dan prototyping. Tahap prototyping terdiri dari experts review, one-to-one, dan small group. Penelitian ini dilaksanakan pada bulan April 2018, dan siswa XI MIPA A SMAN 6 Kota Bengkulu sebagai subjek penelitian ini. Diperoleh 8 soal yang dinyatakan valid oleh ulasan 3 pakar, dan 6 dari 8 soal dinyatakan sebagai soal yang baik (terstandar) berdasarkan kategori tingkat kesukaran dan indeks daya beda.
\end{abstract}

Kata kunci: soal esai, pemecahan masalah matematika

\begin{abstract}
The purpose of this study is to produce valid and practical standard questions based on the ability to solve the mathematical problem of high school students. This research was conducted using the Tessmer procedure which consists of preliminary, self-evaluation, and prototyping stages. The prototyping stages consist of expert reviews, one-to-one, and small groups. This research was conducted in April 2018 and the subjects of this study were students of XI MIPA A SMAN 6 Bengkulu. The results of this research were obtained 8 problems that were declared valid by the reviews of 3 experts and 6 out of 8 problems were stated as good (standardized) problems based on the difficulty level category and the discriminating power index.
\end{abstract}

Keywords : essay problems, mathematical problem solving

\section{PENDAHULUAN}

Mata pelajaran matematika pada Tingkat Sekolah Menengah Atas (SMA) memiliki tujuan yang penting. Berdasarkan permendikbud nomor 59 tahun 2014, pembelajaran matematika SMA bertujuan memahami konsep matematika, memecahkan masalah, menggunakan penalaran matematis, mengkomunikasikan masalah secara matematis, dan memiliki sikap dan perilaku yang sesuai dengan nilai dalam matematika.

Berdasarkan tujuan tersebut salah satu kompetensi yang harus dimiliki siswa adalah kemampuan pemecahan masalah matematis. Menurut Fadillah (2009:2), "kemampuan pemecahan masalah matematis merupakan suatu aktivitas kognitif yang kompleks, sebagai proses untuk mengatasi suatu masalah yang ditemui dan untuk menyelesaikannya diperlukan sejumlah strategi”. 
Pentingnya pemecahan masalah dikemukakan Branca (Effendi, 2012:2), bahwa kemampuan pemecahan masalah adalah jantungnya matematika. Sumarmo (2012:13) juga menyatakan bahwa melalui pemecahan masalah matematis siswa dapat: (1) mengidentifikasi kecukupan data untuk pemecahan masalah; (2) membuat model matematika dari suatu situasi atau masalah sehari-hari dan menyelesaikannya; (3) memilih dan menerapkan strategi untuk menyelesaikan masalah matematika dan atau di luar matematika; (4) menjelaskan dan menginterpretasikan hasil sesuai permasalahan asal, serta memeriksa kebenaran hasil atau jawaban; (5) menerapkan matematika secara bermakna.

Walaupun kemampuan pemecahan masalah matematis sangat penting tetapi kenyataannya pada saat ini kemampuan pemecahan masalah matematis yang dimiliki siswa masih rendah. Hal ini sebagaimana yang dikemukakan oleh Pijateng (2006) bahwa nilai pemecahan masalah sebagian siswa di beberapa tempat, tidak lebih dari kemampuan matematis yang lain. Senada juga yang disampaikan oleh Suci dan Rosyidi (2012), bahwa "pembelajaran matematika di sekolah selama ini kurang memberikan kesempatan bagi siswa dalam mengembangkan kemampuan pemecahan masalah matematis siswa", sehingga dampaknya siswa memiliki kemampuan pemecahan masalah matematis yang belum memadai.

Menurut Suryadi dan Herman (2008 : 68), "Jika seorang anak dihadapkan pada suatu masalah matematika dan anak tersebut langsung dapat tahu cara menyelesaikannya dengan benar, maka masalah yang diberikan tidak dapat digolongkan kepada kategori soal pemecahan masalah". Kenyataaanya, di beberapa sekolah berdasarkan observasi di sekolah, soal yang ditemukan untuk latihan masih sebatas penyelesaian yang langsung dapat diketahui cara menyelesaikannya. Soal tersebut dapat dilihat pada gambar 1. Soal semacam ini tentu belum dapat melatih kemampuan pemecahan masalah matematis siswa secara baik.

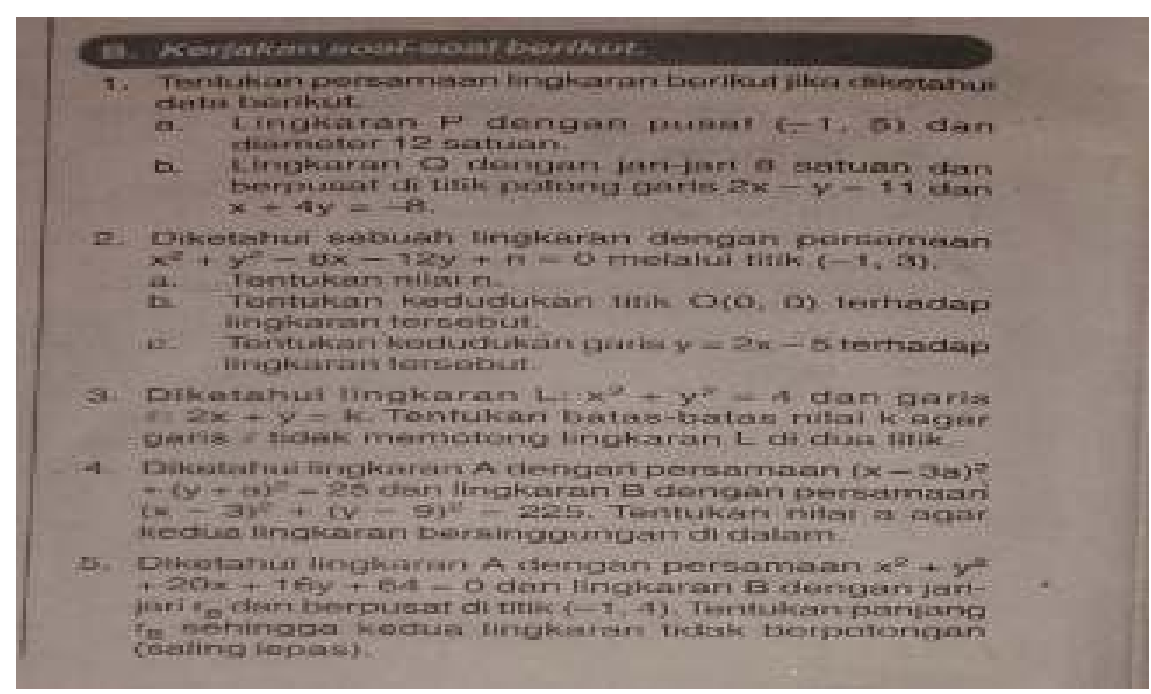

Gambar 1. Soal yang digunakan sekolah

Untuk mengembangkan kemampuan pemecahan masalah matematis siswa, salah satunya dengan sering berlatih menyelesaikan soal-soal berbasis pemecahan masalah matematis. "Suatu soal pemecahan masalah biasanya memuat suatu situasi yang dapat mendorong seseorang untuk menyelesaikannya, akan tetapi tidak secara langsung tahu caranya" (Suryadi dan Herman, 2008:68). 
Tipe soal yang tepat digunakan untuk pemecahan masalah ialah soal uraian. Dengan menyelesaikan soal bertipe uraian, siswa dapat mengorganisasikan gagasan atau hal-hal yang dipelajarinya dengan cara mengemukakan atau mengekspresikan gagasan tersebut dalam bentuk uraian dengan menggunakan kata-kata atau kalimat sendiri (Departemen Pendidikan dan Kebudayaan 1999:49). Demikian juga disampaikan oleh Kusaeri dan Suprananto (2012:137) bahwa soal bentuk uraian memiliki kelebihan anatara lain dapat mengukur kemampuan siswa dalam hal menyajikan jawaban terurai secara bebas, mengorganisasikan pikirannya, mengemukakan pendapatnya, dan mengekspresikan gagasa-gagasan dengan menggunakan kata-kata atau kalimatnya sendiri. Sementara untuk melatih kemampuan mengekspresikan ide dan gagasannya dalam memecahkan masalah, diperlukan banyak soal terstandar untuk mengembangkan kemampuan pemecahan masalah matematis siswa. Soal terstandar yaitu soal yang valid dan memiliki tingkat kesukaran dan indeks daya beda yang baik. Untuk itu soal harus disusun secara sistematis dan prosedural baik secara kualitatif dan kuantitatif. Melalui proses analisis kualitatif oleh validator, akan menghasilkan soal yang valid dan melalui proses ujicoba ke lapangan (small group) serta analisisnya dapat diperoleh bukti empiris tentang tingkat kesukaran dan indeks daya beda butir soal yang dikembangkan tersebut.

Berdasarkan uraian di atas, intinya, bahwa kemampuan pemecahan masalah matematis siswa perlu dikembangkan secara terus menerus, dan untuk itu salah satunya perlu dilatih dengan menyelesaikan banyak soal-soal pemecahan masalah matematis yang terstandar.

Tujuan penelitian ini adalah untuk menghasilkan soal kemampuan pemecahan masalah matematis yang terstandar, yaitu soal yang memiliki tingkat kesukaran dan indeks daya beda yang baik untuk mengembangkan kemampuan pemecahan masalah matematis siswa SMA kelas XI.

\section{METODE}

Jenis penelitian ini adalah penelitian pengembangan. Penelitian ini dilaksanakan di SMAN 6 Kota Bengkulu, subjek pada penelitian ini siswa kelas XI MIPA yang terdiri dari 30 siswa. Penelitian dilaksanakan pada bulan April 2018.

Penelitian pengembangan ini mengikuti alur penelitian model Tessmer (1993). Model pengembangan Tessmer terdiri dari tahap preliminary, self evaluation, dan prototype. Prototype meliputi experts review, one-to-one dan small group. Bentuk diagram alir dari penelitian pengembangan ini ialah sebagai berikut :

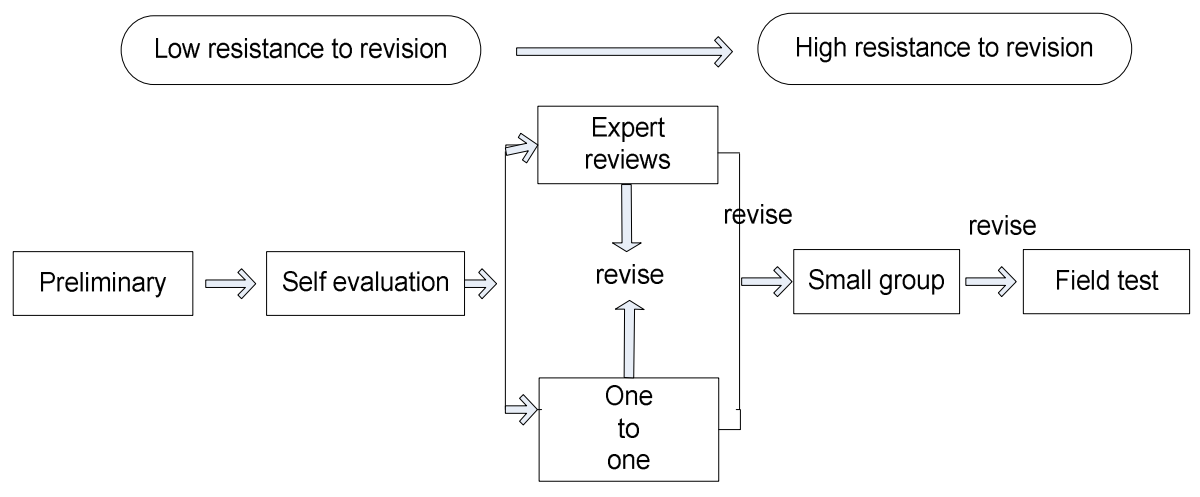

Gambar 2. Alur desain Tessmer (Tessmer, 1993; Zulkardi, 2006) 
Setelah diperoleh keputusan bahwa soal-soal yang dikembangkan ini telah valid berdasarkan experts review, dan one to one untuk memastikan bahwa soal-soal tersebut 'terbaca' oleh siswa (testi), selanjutnya soal-soal ini diujicobakan pada small grup untuk memperoleh informasi tentang tingkat kesukaran (pi) dan indeks daya beda masing-masing butir soal.

Tingkat kesukaran butir soal (pi) dapat diperoleh dengan menggunakan rumus:

$$
\text { pi }=\frac{\text { jumlah skor butir } \text { i yang diperoleh seluruh testi }}{\text { (nilai maksimum butir } \text { i) } x(\text { jumlah seluruh testi) }} \quad \text { (Allen and Yen, 1979) }
$$

Angka indeks daya pembeda soal (di) diperoleh dengan menggunakan rumus:

$$
\mathrm{di}=\frac{U i}{n i U}-\frac{L i}{n i L}
$$

Ui : jumlah skor kelompok atas

Li : jumlah skor kelompok bawah

niU : (banyak testi kelompok atas) x (skor maksimum butir i)

niL : (banyak testi kelompok bawah) $\mathrm{x}$ (skor maksimum butir i)

(Allen and Yen, 1979)

Kriteria soal yang terstandar untuk kemampuan pemecahan masalah matematis siswa pada penelitian ini ialah :

1. Soal harus valid secara kualitatif berdasarkan konten, konstruk dan bahasa.

2. Soal praktis 'terbaca' atau komunikatif/dapat dipahami testi.

3. Soal terkategori baik secara kuantitatif dengan ketentuan bahwa tingkat kesukaran (pi) soal berada pada kategori sedang yaitu $0,30 \leq \mathrm{p} \leq 0,70$ dan Indeks daya beda soal $(d i) \geq 0,2$ (Depdikbud, 1999)

\section{HASIL DAN PEMBAHASAN}

Ada empat tahap penelitian ini, yaitu preliminary, self evaluation, experts reviews dan one-to-one, small group. Kegiatan yang dilakukan dalam penelitian pengembangan soal ini adalah sebagai berikut :

1. Preliminary

a. Persiapan

Pada tahap ini yang dilakukan adalah melihat masalah yang ada di sekolah. Masalah yang ditemukan yaitu belum adanya soal untuk kemampuan pemecahan masalah matematis siswa pokok bahasan lingkaran. Sementara soal tersebut diperlukan untuk melatih dan mengetahui kemampuan pemecahan masalah matematis siswa. Setelah mengidentifikasi masalah yang ada, ditentukan tempat yang dijadikan penelitian yaitu SMAN 6 Kota Bengkulu. Selanjutnya mengatur jadwal penelitian dan prosedur kerja sama dengan guru mata pelajaran matematika. Selain itu juga dilakukan :

1) Analisis Siswa

Didapatkan subjek penelitian yaitu siswa kelas XI MIPA A SMAN 6

Kota Bengkulu sebanyak 31 siswa dimana siswa tersebut memiliki kemampuan yang heterogen, dilihat berdasarkan hasil ujian siswa sehingga siswa dikelompokkan menjadi siswa berkemampuan tinggi, siswa 
berkemampuan sedang dan siswa berkemampuan rendah. Pada analisis siswa juga diketahui bahwa siswa sudah pernah mempelajari materi lingkaran sebelumnya di SMP, sehingga banyak konsep-konsep mengenai lingkaran yang diketahui siswa.

2) Analisis Kurikulum

Kurikulum yang digunakan di SMAN 6 Kota Bengkulu adalah kurikulum 2013 yang salah satu tujuan pembelajarannya adalah kemampuan pemecahan masalah matematis. Dari kegiatan ini diperoleh Kompetensi Inti (KI) yaitu memahami, menerapkan, dan menganalisis pengetahuan faktual, konseptual, prosedural, dan metakognitif berdasarkan keingintahuannya tentang ilmu pengetahuan, teknologi, seni, budaya dan humaniora dengan wawasan kemanusiaan, kebangsaan, kenegaraan dan peradaban terkait penyebab fenomena dan kejadian serta menerapkan pengetahuan prosedural pada bidang kajian yang spesifik sesuai dengan bakat dan minatnya untuk memecahkan masalah serta mengolah, menalar dan menyaji dalam ranah konkret dan ranah abstrak terkait dengan pengembangan dari yang dipelajarinya di sekolah secara mandiri, bertindak secara efektif dan kreatif, serta mampu menggunakan metoda sesuai kaidah keilmuan. Kompetensi Dasar (KD) yaitu menganalisis lingkaran secara analitik dan menyelesaikan masalah yang terkait dengan lingkaran. Serta silabus mata pelajaran Matematika SMA kelas XI materi lingkaran yang meliputi kompetensi inti, kompetensi dasar, materi pokok, rubrik penilaian, alokasi waktu dan sumber buku pelajaran.

3) Analisis Materi

Materi yang digunakan dalam penelitian ini adalah materi lingkaran kelas XI SMA. Pada silabus mata pelajaran matematika SMA dengan materi pokok lingkaran memiliki alokasi waktu pembelajaran sebanyak $15 \times 45$ menit (15 Jam Pelajaran). Selanjutnya dari silabus tersebut dipilih sub pokok bahasan yang akan digunakan untuk membuat soal dan indikator masingmasing soal. Materi lingkaran ini menggunakan pendekatan kontekstual karena banyak sekali keterkaitan konsep-konsep lingkaran yang digunakan dalam kehidupan sehari-hari. Kontekstual merupakan konsep belajar yang mengaitkan materi pelajaran dengan kehidupan sehari-hari.

b. Pendesainan

Soal didesain sebanyak 8 soal berbentuk essay, menggunakan bahasa yang tepat dan sesuai EYD agar dapat dipahami oleh semua siswa. Desain soal meliputi pedoman penskoran, kunci jawaban dan kisi-kisi soal yang berisi tentang: 1) Kompetensi Inti; 2) Kompetensi Dasar; 3) Materi; 4) Indikator Kemampuan Pemecahan Masalah Matematis; 5) Indikator Materi masing-masing; 6) Butir Soal. Hasil desainnya disebut prototype.

\section{Self Evaluation}

Pada tahap ini, prototype yang berjumlah 8 soal dan telah didesain dinilai sendiri sebelum divalidasi oleh pakar. Penilaian terhadap soal dilakukan dari segi konten, konstruk dan bahasa. Setelah mendapatkan kesalahan pada prototype yang berupa penulisan kalimat dalam soal, beberapa angka dan tata letak selanjutnya prototype dibenahi dan divalidasi oleh pakar. 


\section{Experts Review}

Pada tahap ini prototype yang telah didesain divalidasi oleh tiga validator yaitu dua orang dosen Pendidikan Matematika Universitas Muhammadiyah Bengkulu dan satu orang guru Matematika SMAN 6 Kota Bengkulu untuk memperoleh soal yang valid dari segi konten, konstruk dan bahasa. Pada proses validasi pakar diberikan soal dan lembar validasi, kisi-kisi soal serta kunci jawaban. Pada validasi pertama validator berpendapat prototype masih memiliki sedikit kesalahan dan perlu dilakukan revisi, berikut adalah salah satu hasil experts review.

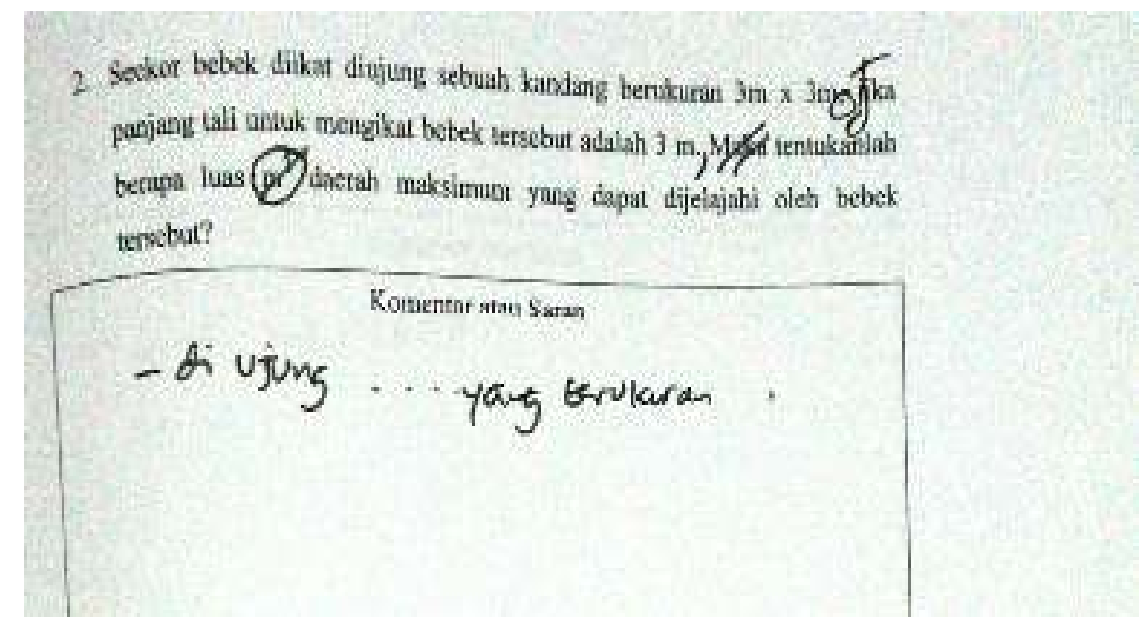

Gambar 3. Salah satu hasil expert review

Pada proses validasi yang kedua prototype sudah dinyatakan valid oleh ketiga validator.

\section{One to one}

Pada tahap ini soal dipastikan keterbacaannya oleh siswa. Dipilih 3 orang siswa yang memiliki kemampuan berbeda-beda. Masing-masing siswa memberikan komentar pada setiap soal. Berdasarkan komentar siswa, sebagian besar siswa sudah memahami soal (terbaca) sesuai dengan alur pikirannya. Hal ini dapat dilihat pada tabel 1 berikut.

Tabel 1. Komentar/saran siswa pada tahap one-to-one terhadap soal yang dikembangkan

\begin{tabular}{clll}
\hline \multirow{2}{*}{ No. } & \multicolumn{4}{c}{ Komentar/saran siswa terhadap soal } \\
\hline & \multicolumn{1}{c}{ Subjek 1 } & \multicolumn{1}{c}{ Subjek 2 } & \multicolumn{1}{c}{ Subjek 3 } \\
\hline 1 & Soal dapat dipahami & Soal dapat dipahami & Soal dapat dipahami \\
\hline 2 & Soal dapat dipahami & $\begin{array}{l}\text { Soal dapat dipahami dan } \\
\text { soal jelas tetapi masih } \\
\text { kurang mengerti ujung } \\
\text { kandang terletak di } \\
\text { sebelah mana }\end{array}$ & $\begin{array}{l}\text { Soal bisa dipahami, } \\
\text { mengecoh }\end{array}$ \\
\hline 3 & Soal sudah cukup jelas & Soal dapat dipahami & \\
\hline 4 & Soal dapat dipahami & Soal dapat dipahami & Paham \\
\hline 5 & $\begin{array}{l}\text { Soal cukup jelas tetapi } \\
\text { memahaminya } \\
\text { membutuhkan }\end{array}$ & $\begin{array}{l}\text { Soal jelas tetapi sedikit } \\
\text { pusing }\end{array}$ & $\begin{array}{l}\text { Soal cukup jelas dan } \\
\text { lumayan susah }\end{array}$ \\
\hline
\end{tabular}




\begin{tabular}{clll}
\hline & $\begin{array}{l}\text { lebih banyak daripada } \\
\text { soal sebelumnya }\end{array}$ & & \\
\hline 6 & $\begin{array}{l}\text { Soal dapat dipahami } \\
\text { Soal lumayan susah }\end{array}$ & $\begin{array}{l}\text { Soal cukup jelas dan } \\
\text { dapat dipahami }\end{array}$ & Soal dapat dipahami \\
\hline 7 & Soal dapat dipahami & Soal lumayan susah & Soal dapat dipahami \\
\hline 8 & $\begin{array}{l}\text { Soal dapat dipahami } \\
\text { Cukup jelas }\end{array}$ & $\begin{array}{l}\text { Soal cukup jelas } \\
\text { mengerti }\end{array}$ & Soal cukup jelas \\
\hline
\end{tabular}

Pada tabel 1 terlihat bahwa siswa paham (terbaca) dengan soal-soal tersebut, walaupun perlu waktu untuk memahaminya, sehingga soal-soal ini dapat diteruskan proses pengembangannya.

\section{Small Group}

Pada tahap ini soal diujikan kepada siswa-siswi kelas XI MIPA A SMAN 6 Kota Bengkulu, sebagai subjek ujicoba untuk diketahui tingkat kesukaran dan indeks daya beda setiap butir soal. Dari 8 soal yang diujicobakan diperoleh 6 butir soal yang baik (terstandar) berdasarkan kategori tingkat kesukaran dan indeks daya beda masing-masing butir secara simultan. Pada tabel 2 diperlihatkan kesimpulan hasil analisis ujicoba tersebut.

Tabel 2. Kesimpulan hasil analisis ujicoba soal yang dikembangkan

\begin{tabular}{cccccc}
\hline $\begin{array}{c}\text { Butir } \\
\text { soal }\end{array}$ & pi & Keterangan & di & Keterangan & Kesimpulan \\
\hline 1 & 0,709 & Tidak baik & 0,075 & Tidak baik & Tidak baik \\
2 & 0,616 & Baik & 0,325 & Baik & Baik \\
3 & 0,654 & Baik & 0,362 & Baik & Baik \\
4 & 0,641 & Baik & 0,35 & Baik & Baik \\
5 & 0,587 & Baik & 0,3 & Baik & Baik \\
6 & 0,803 & Tidak baik & 0,212 & Baik & Tidak baik \\
7 & 0,690 & Baik & 0,337 & Baik & Baik \\
8 & 0,541 & Baik & 0,537 & Baik & Baik \\
\hline
\end{tabular}

Tabel 2 memuat hasil analisis kuantitatif tingkat kesukaran butir soal (Pi) dan indeks daya beda butir soal (di). Soal yang terstandar adalah soal yang memiliki karakter tingkat kesukaran $0,30 \leq$ pi $\leq 0,70$ dan indeks daya beda (di) $\geq 0,2$.

Soal-soal yang dikembangkan dalam penelitian ini dan telah melalui proses pengembangan soal sedemikian rupa hingga dari 8 soal yang didesain sudah valid pada analisis kualitatif (experts review dan one-to-one) dan dilanjutkan pada tahap analisis kuantitatif (small group) yang menghasilkan 6 butir soal dalam kategori karakteristik butir soal terstandar yaitu butir soal nomor 2, 3, 4, 5, 7, dan 8 . Keenam butir soal ini dinyatakan valid dan praktis.

Berikut ini adalah soal final yang diujikan kepada siswa kelas XI SMAN 6 Kota Bengkulu untuk memperoleh karakteristik butir soal yaitu tingkat kesukaran dan indeks daya beda masing-masing butir soal tersebut. Tabel 3 memperlihatkan soal-soal yang valid yang siap diujikan pada tahap small group. 
Tabel 3. Soal yang valid siap diujikan untuk memperoleh data tingkat kesukaran dan indeks daya beda setiap butir soal

\begin{tabular}{lc}
\hline No & Soal \\
\hline 1 & Seorang pengusaha akan membuat bianglala seperti yang ada di taman
\end{tabular}
wisata Jungle Land Bogor di bawah ini.

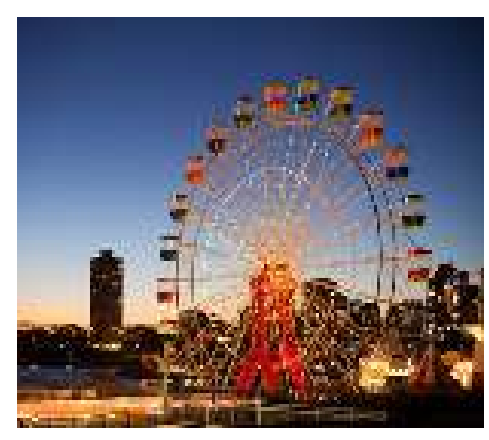

Jika tempat duduk pada bianglala sebanyak 25 buah dengan jarak masingmasing busur antara tempat duduk adalah 2 meter, berapakah panjang diameter bianglala tersebut ?

2 Seekor bebek diikat di ujung sudut sebuah kandang yang berukuran $3 \mathrm{mx} 3 \mathrm{~m}$. Jika panjang tali untuk mengikat bebek tersebut adalah $3 \mathrm{~m}$, tentukanlah berapa luas daerah maksimum yang dapat dijelajahi oleh bebek tersebut?

3 Suatu kapal pesiar yang berada pada koordinat $(7,18)$ memiliki radar dengan jangkauan $50 \mathrm{~km}$ ke segala arah. Tulislah persamaan yang memodelkan jangkauan maksimum dari radar kapal tersebut !

4 Suatu pemancar stasiun televisi berada pada koordinat $(9,4)$. Jika pemancar stasiun televisi tersebut mempunyai jangkauan gelombang sejauh $1000 \mathrm{~km}$, maka tentukan persamaan gelombang televisi tersebut.

5 Andi sedang mengamati seorang bapak yang sedang berlari pagi mengelilingi taman berbentuk lingkaran. Jarak lintasan bapak tersebut dengan pusat lingkaran adalah 10 meter, sedangkan jarak Andi terhadap pusat taman adalah 15 meter . Jika posisi tempat Andi melihat dinyatakan sebagai titik awal koordinat kartesius. Tentukan persamaan lintasan yang dibuat oleh bapak tersebut?

6 Titik pusat suatu gempa terletak pada koordinat $(4,8)$ di peta dan memiliki radius $40 \mathrm{~km}$. Apakah seseorang yang berada pada koordinat $(30,49)$ juga dapat merasakan gempa ? 
7 Hitunglah luas daerah berwarna putih yang diameternya melewati sumbu $\mathrm{x}$ dan jari-jari lingkaran berwarna hitam 1 satuan panjang.

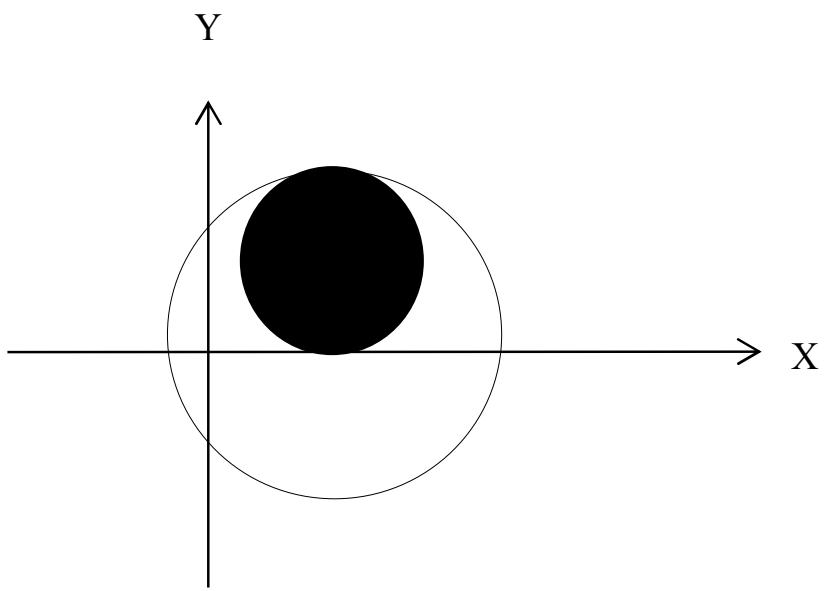

8 Diketahui stasiun televisi A memiliki jangkauan siaran yang dibatasi oleh daerah $\mathrm{x}^{2}+\mathrm{y}^{2}+8 \mathrm{x}-6 \mathrm{y}=0$ dan stasiun televisi B memiliki jangkauan siaran yang dibatasi oleh daerah $x^{2}+y^{2}+4 x+6 y=0$. Kedua stasiun televisi tersebut tidak akan menggunakan daerah yang sama apabila daerah siarannya beririsan. Lukislah kedua daerah siaran televisi tersebut dan tunjukkan bahwa kedua stasiun tersebut memiliki frekuensi yang sama dilihat dari titik koordinatnya.

\section{SIMPULAN DAN SARAN}

Setelah melalui proses pengembangan soal telah dihasilkan soal matematika untuk kemampuan pemecahan masalah matematis siswa SMA yang valid dan praktis (terbaca) sebanyak 8 soal. Valid tergambar dari hasil penilaian experts review berdasarkan konten, konstruk dan bahasa. Soal terbaca yang terlihat dari komentar siswa, sebagian besar siswa memahami soal sesuai dengan alur pikiran siswa. Dari 8 soal kemampuan pemecahan masalah matematis yang dikembangkan yang valid (analisis kualitatif) ini, sebanyak 6 soal termasuk kriteria yang terstandar dilihat dari indeks daya beda dan tingkat kesukaran (kuantitatif) setiap butir soal.

Kedelapan soal ini dapat digunakan untuk melihat dan menguji kemampuan pemecahan masalah matematis siswa SMA, khususnya pada materi lingkaran.

\section{DAFTAR PUSTAKA}

Allen and Yen. 1979. Introduction to Measurement Theory. California: Cece Munshon.

Departemen Pendidikan dan Kebudayaan. 1999. Pengelolaan Pengujian. Jakarta: Direktorat Pendidikan Menengah Umum.

Effendi, L.A. 2012. Pembelajaran Matematika dengan Metode Penemuan Terbimbing Untuk Meningkatkan Kemampuan Representasi dan Pemecahan Masalah Matematis Siswa. Jurnal Penelitian Pendidikan Vol. 12(2). [Online]. Tersedia : http://jurnal.upi.edu/file/Leo_Adhar.pdf. [13 Januari 2018]. 
Fadillah, S. 2009. Kemampuan Pemecahan Masalah Matematis Dalam Pembelajaran Matematika. Makalah Pada Prosiding Seminar Nasional Penelitian, Pendidikan dan Penerapan MIPA Fakultas MIPA, Universitas Negeri Yogyakarta, 16 Mei 2009. ISSN 978-979-96880-5-7. [Online]. Tersedia : https://eprints.uny.ac.id/12317/ [1 Februari 2018].

Kusaeri dan Suprananto. 2012. Pengukuran dan Penilaian Pendidikan. Yogyakarta: Graha Ilmu.

Permendikbud nomor 59 tahun 2014. [Online]. Tersedia : https://suaidinmath.wordpress.com/2014/09/10/permendikbud-tentangkurikulum-2013-sekolah-menengah-atasmadrasah-aliyah/ [ Februari 2018].

Pijateng. 2006. Peningkatan Kemampuan Pemecahan Masalah dengan Pembelajaran Kontekstual dan Penggunaan Open-Ended Problems. Jurnal Kependidikan, Nomor 1, Tahun XXXVI : 53-68.

Suci, A.A.W dan Rosyidi, A.H. 2012. Kemampuan Pemecahan Masalah Matematika Siswa pada Pembelajaran Problem Posing Berkelompok. Jurnal MATHEdunesa, Vol. 1(2). [Online]. https://jurnalmahasiswa.unesa.ac.id.pdf. [1 Februari 2018].

Sumarmo, U. 2012. Pendidikan Karakter Serta Pengembangan Berfikir dan Disposisi Matematika dalam Pembelajaran Matematika. [Online]. Tersedia : https://utari-sumarmo.dosen.stkipsiliwangi.ac.id.pdf. [12 Februari 2018].

Suryadi, D. dan Herman, T. 2008. Eksplorasi Matematika Pembelajaran Pemecahan Masalah. Jakarta: Karya Duta Wahana.

Tessmer, Martin. 1993. Planning and Conducting Formative Evaluations. Philadelphia: Kogan Page.

Zulkardi. 2006. Formative Evaluation: What, Why, When, and How. [Online]. Tersedia : http://www.oocities.org/zulkardi/books.html. [Desember 2017]. 